\title{
Antiluteolytic mechanisms and the establishment of pregnancy in the pig
}

\author{
A. Waclawik, A. Blitek, M.M. Kaczmarek, J. Kiewisz and A.J. Ziecik \\ Institute of Animal Reproduction and Food Research of Polish Academy of Sciences, \\ Tuwima 10, 10-747 Olsztyn, Poland
}

\begin{abstract}
Extended exposure of progesterone and conceptus estrogen influences the vascular compartment of the uterus and expression of many factors, such as prostaglandins (PGs), growth factors, extracellular matrix and adhesion molecules, cytokines and transcription factors. One of the supportive mechanisms by which the conceptus inhibits luteolysis is by changing PG synthesis in favor of luteoprotective PGE2. Alteration in PG synthesis may result from increased PGE synthase (mPGES-1) expression in the trophoblast and endometrium on days 10-13 of pregnancy with simultaneous down-regulation of PGF synthase (PGFS) and prostaglandin 9-ketoreductase (CBR1). Conceptus and endometrial, rather than luteal, synthesis of PGE2, is involved in the process of maternal recognition of pregnancy. However, complex (direct and indirect) actions of estrogen on the $\mathrm{CL}$, including decreased luteal VEGF soluble receptor on day 12 of pregnancy, are important for luteal maintenance. Moreover, conceptus signals affect another lipid signaling component - lysophosphatidic acid receptor (LPA3), as well as HoxA10 and Wnt in the endometrium, to create the appropriate uterine environment for establishment of pregnancy and implantation.
\end{abstract}

\section{Antiluteolytic mechanisms}

In pigs, corpora lutea $(C L)$ regression on days $15-16$ of the estrous cycle results from an increase in pulsatile endometrial secretion of prostaglandin F2 $\alpha$ (PGF2 $\alpha$ ) (for review, see Bazer et al. 1982). Basal PGF $2 \alpha$ release by endometrium increases 3 -fold between day 5 and 14 of the estrous cycle (Stepien et al. 1999). According to Krzymowski \& Stefanczyk-Krzymowska (2008), the PGF $2 \alpha$ pulsatile elevation in the blood outflowing from the uterus during luteolysis and shortly afterwards, results from decreased blood flow in the endometrium and excretion of PGF $2 \alpha$ and its metabolites to lymph, blood and tissue fluids which accumulate PGs. However, oxytocin, luteinizing hormone (LH) and tumor necrosis factor $\alpha$ should be considered as potential modulators of endometrial PGF $2 \alpha$ production during luteolysis (Uzumcu et al. 1998, Blitek \& Ziecik 2006, Blitek et al. 2007).

The porcine $\mathrm{CL}$ is unusual among domestic animals because it does not display a luteolytic response to exogenous PGF $2 \alpha$ until days $12-13$ of the estrous cycle. The insensitivity of early $\mathrm{CL}$ to exogenous PGF $2 \alpha$ is explained partially by low number of luteal PGF2 $\alpha$ receptors (FPr) (Boonyaprakob et al. 2003) and a deficiency in post-FPr signaling (Zorrilla et al. 2009). Lower FPr concentration on day 14 of pregnancy/pseudopregnancy in comparison to the estrous cycle suggests that conceptus signals may inhibit FPr expression in the CL (Gadsby et al. 1993). The 
role of oxytocin in controlling PGF $2 \alpha$ secretion is not as well defined as in ruminants (for review see, Ziecik et al. 2006). Systemic infusions of oxytocin-antagonist between days 12 and 20 of the estrous cycle reduce amplitude of PGFM (PGF2 $\alpha$ metabolite) pulses, but does not prevent luteolysis (Kotwica et al. 1999). Surprisingly, oxytocin concentration in the uterine lumen significantly increases on days 12-14 of pregnancy when compared to corresponding days of the estrous cycle (Vallet et al. 1998). Moreover, oxytocin is not luteolytic when administered locally to the uterine lumen as it is when administered systemically (Sample et al. 2000) and intra-uterine infusion of oxytocin decreases plasma concentrations of PGFM on day 16 after estrus (Sample et al. 2004).

Maternal recognition of pregnancy (days 11-13) and implantation (days 14-19) are critical for $\mathrm{CL}$ maintenance and pregnancy establishment. Maternal recognition of pregnancy occurs simultaneously with rapid transformation of trophoblast from spherical to tubular then filamentous forms between days 10-12 just prior to implantation. During this period, conceptuses secrete elevated levels of estrogens, mainly estradiol-17ß. A second, more sustained increase of estrogen secretion is observed between days 15 and 25-30 of pregnancy (Geisert et al. 1990). Inhibition of luteolysis and establishment of pregnancy in pigs require this biphasic pattern of estrogen secretion that results in prolonged luteal life span and progesterone secretion (for review, see Geisert et al. 1990). Systemic estrogen administration on days 11-15 of the estrous cycle prevents $\mathrm{CL}$ regression and extends $\mathrm{CL}$ life span (Frank et al. 1977). The luteoprotective action of estrogen is complex (Fig. 1). Estrogen stimulates luteal progesterone secretion directly (Conley \& Ford 1989) as well as by increasing luteal LH receptor (LHR) concentration (Garverick et al. 1982) and by decreasing PGF2 $\alpha$ release from uterus into peripherial circulation (Moeljono et al. 1977, Bazer \& Thatcher 1977).

Estrogen receptor (ESR) expression in luminal (LE) and glandular epithelium (GE) of the endometrium (Geisert et al. 1993) and in the conceptus (Kowalski et al. 2002) coincides with estrogen secretion from the conceptus, which suggests both autocrine and paracrine responses. Both sufficient conceptus estrogen secretion (less than 2 conceptuses in each horn results in pregnancy failure) and timing of endometrial exposure to estrogen is critical for establishment of pregnancy. Early administration of estrogen on days 9-10 of pregnancy results in embryonic loss and altered endometrial expression of many genes, during later pregnancy, probably causing desynchronization of the uterine environment and conceptus implantation (Geisert et al. 2006). Included among the altered genes is an enzyme involved in PG synthesis (prostaglandin-endoperoxide synthase 2; PTGS2).

Endometrial function and conceptus development during the peri-implantation period of pregnancy are uniquely regulated through interacting effects of progesterone from the $\mathrm{Cl}$ and estrogen from the conceptus. Estrogen is suggested to be involved in changes of uterine secretory activity (Geisert et al. 1982), increased blood flow (for review see, Bazer et al. 1982), endometrial edema (Laforest \& King 1992), and regulation of endometrial expression of many factors (Fig. 1). However, other reports indicate that concentrations of many proteins within the uterine lumen during early pregnancy are independent of the presence of the conceptus (Vallet et al. 1998, Kayser et al. 2006).

Factors involved in PG synthesis and signaling during inhibition of luteolysis and pregnancy establishment

Concentrations and peak amplitude of PGF $2 \alpha$ in utero-ovarian vein plasma are higher in cyclic than in pregnant gilts on days 12-17 (Bazer \& Thatcher 1977, Moeljono et al. 1977). Moreover, uterine flushings of pregnant pigs contain higher amounts of PGF2 $\alpha$ than those from 


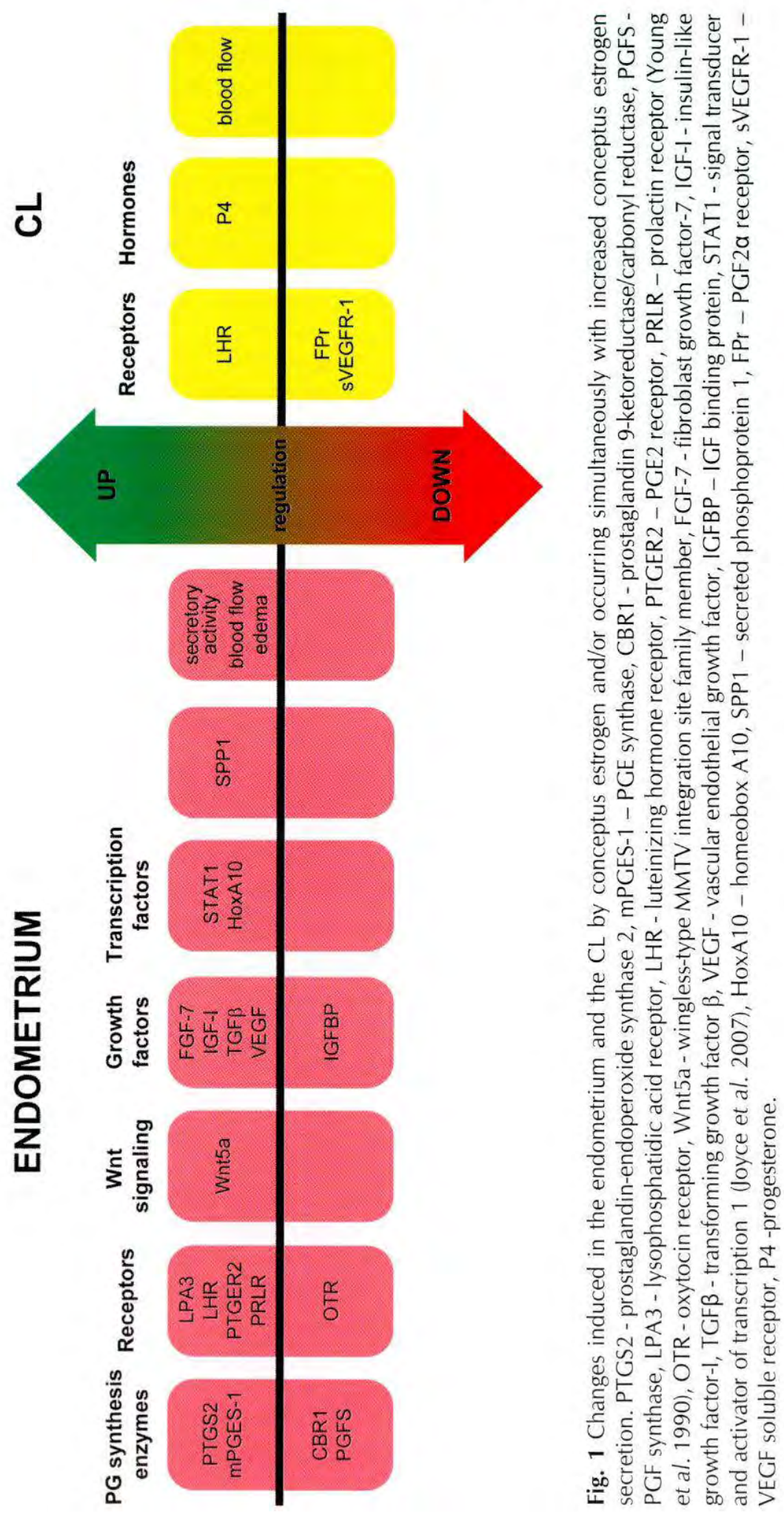


cyclic animals (Zavy et al. 1980). This may be explained by the proposed theory that during maternal recognition of pregnancy, conceptus estrogen redirects PGF $2 \alpha$ secretion from the uterine venous drainage (endocrine) to the uterine lumen (exocrine) (Bazer \& Thatcher 1977). A part of the putative antiluteolytic mechanism could also be the retrograde transfer of PGF $2 \alpha$ from venous blood and uterine lymph into the uterine lumen and ability of uterine veins and arterial walls to accumulate PGF2 $\alpha$ (Krzymowski \& Stefanczyk-Krzymowska 2004). However, Hunter \& Poyser (1982) suggested that exocrine redirection of uterine PGF2 $\alpha$ secretion may not provide a full explanation for maintenance of the $\mathrm{CL}$ in pregnancy in pigs, nor may this route of sequestering the luteolytic hormone always be effective.

Conceptus and/or endometrium PGE2 was suggested to have a role in CL protection against luteolytic PGF $2 \alpha$. In contrast to estrogen, intraluteal administration of PGE2 protects individual CL against luteolytic effect of simultaneously administered PGF2 $\alpha$ (Ford \& Christenson 1991). PGE2 is capable of extending CL life span (Akinlosotu et al. 1986). Interestingly, progesterone content is elevated in the blood plasma or luteal tissue after uterine infusions of PGE2 (Akinlosotu et al. 1986) or when increased secretion of PGE2 was observed in the gravid uterus (Christenson et al. 1994). The infusion of PGE2 into the ovarian artery increases the concentration of progesterone in ovarian venous blood on day 13 and 14 of pregnancy (Stefanczyk-Krzymowska et al. 2006). Moreover, higher PGE2/PGF $2 \alpha$ ratio protects against the luteolytic effect of PGF $2 \alpha$ on luteal cells collected on days 10-12 of the estrous cycle and stimulates progesterone and estradiol-17 $\beta$ secretion by these luteal cells (Gregoraszczuk \& Michas 1999).

On days 11-13 of pregnancy, at the time of maternal recognition of pregnancy, the PGE2/PGF2 $\alpha$ ratio in the uterus and uterine vein increases, suggesting that PGE2 helps to overcome the luteolytic effect of PGF $2 \alpha$, thus preventing CL regression (Davis \& Blair 1993, Christenson et al. 1994). Therefore, another potential mechanism by which the conceptus helps to prevent luteolysis is by changing PG synthesis in favor of the luteoprotective PGE2 (Fig. 2), since the endometrium and trophoblast synthesize elevated amounts of PGE2 before implantation (Waclawik et al. 2006, Waclawik \& Ziecik 2007).

PGs are synthesized by PTGS and specific terminal prostaglandin synthases: PGE synthase (mPGES-1) and PGF synthase (PGFS). Moreover, PGE2 can be converted into PGF2 $\alpha$ by prostaglandin 9-ketoreductase/carbonyl reductase (CBR1). Our recent results in vitro indicate that estrogen stimulates PGE2 synthesis through increase of PTGS2 and mPGES-1 gene expression and decreases the content of enzymes involved in PGF2 $\alpha$ production (PGFS and CBR1) in the endometrium on days 11-12 after estrus (Waclawik et al. 2009). It is consistent with findings that mPGES-1 expression is relatively high whereas PGFS and CBR1 expression is low in the endometrium between days 10-13 of pregnancy compared to the implantation period (Waclawik et al. 2006, Waclawik \& Ziecik 2007). Similar, but more pronounced alterations of PG enzyme expression were found in conceptuses (Fig. 3, Waclawik \& Ziecik 2007). Selective changes in PG synthesis enzymes during early pregnancy correspond with estrogen secretion by the conceptus. Endometrial mPGES-1 expression exhibits a biphasic profile, similar to conceptus estrogen. By contrast, rapid increase of PGFS and CBR1 after initiation of implantation corresponds with the decline in conceptus estrogen synthesis. Accordingly, estrogen elevates PGE2 content in the uterus (Geisert et al. 1982) and therefore may be an important factor regulating the PGE2/PGF $2 \alpha$ ratio during early pregnancy.

Our recent studies indicate the existence of a putative PGE2 autoamplification loop in the endometrium that can additionally contribute to the increase of PGE2/PGF2 $\alpha$ ratio during the peri-implantation window. PGE2 acting through endometrial PGE2 receptor (PTGER2) elevates secretion of this prostanoid and expression of the enzymes involved in PGE2 synthesis in the endometrium. Interestingly, endometrial PTGER2 is higher during implantation and can be regulated by estrogen (Waclawik et al. 2009). 


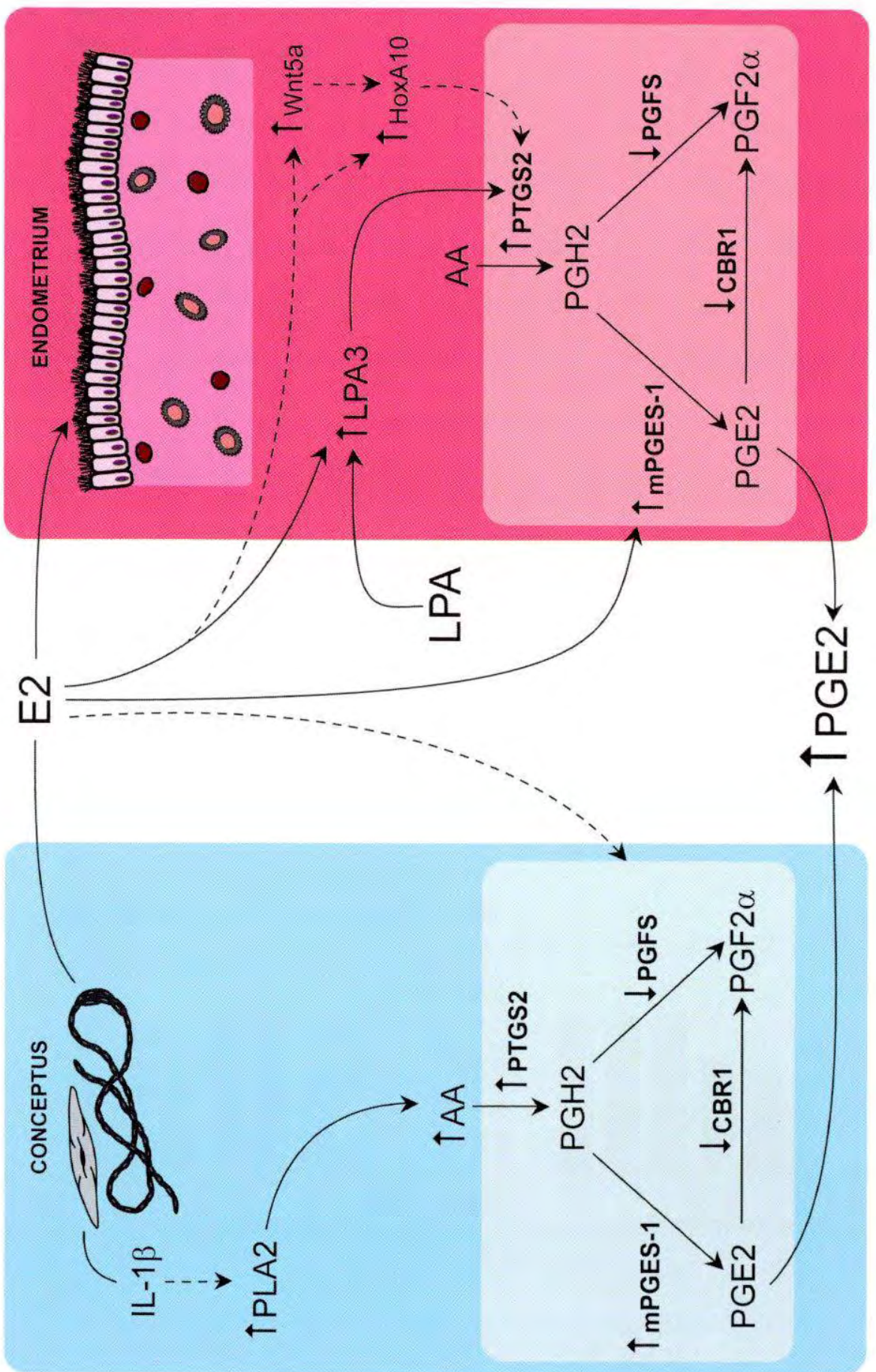

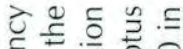
든 $00-5$ 흥 잉

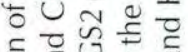
드ㄹㅠㅠ कू

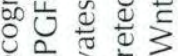
巳一

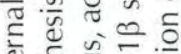

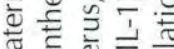
ह क $\stackrel{ \pm}{J} \overline{0}$ Ð

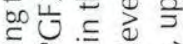

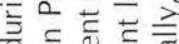
월 Ð

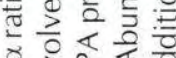
ช 岁:

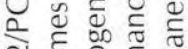
넌

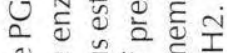
ฯ

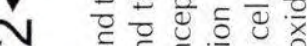
山 ส (1) य

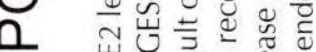

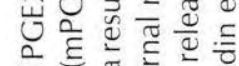

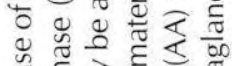
कृ Ф 死 的文标

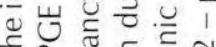

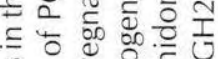

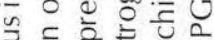

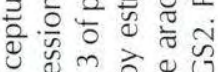
巳 $m$ ह 8 후워 (4) 范

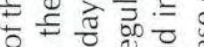

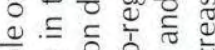
은

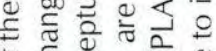
ธ든 는으

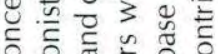

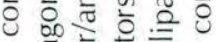
ป⿺辶寸 은 은 О

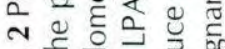

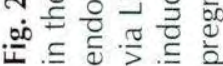


A

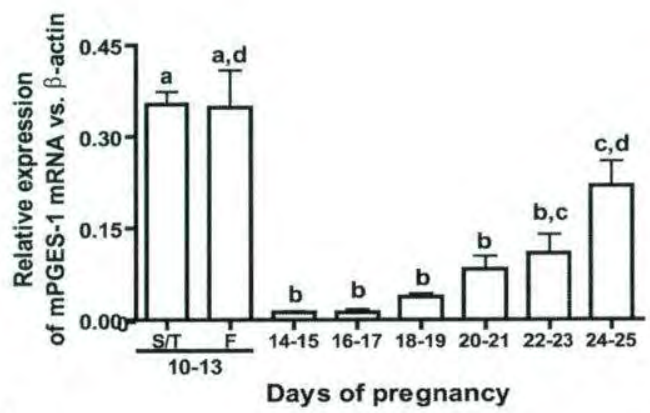

C

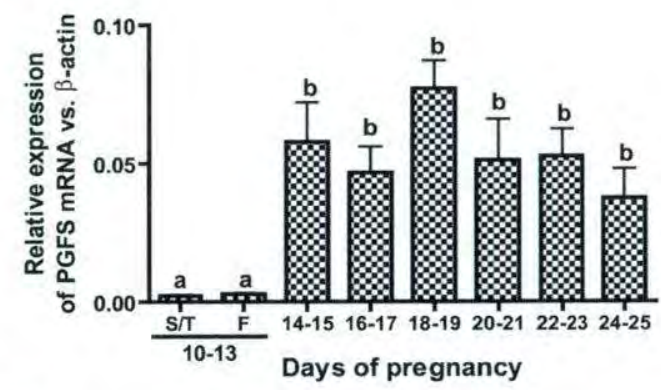

E

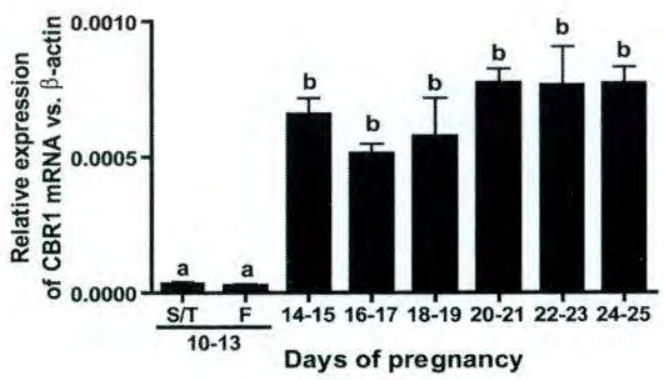

B
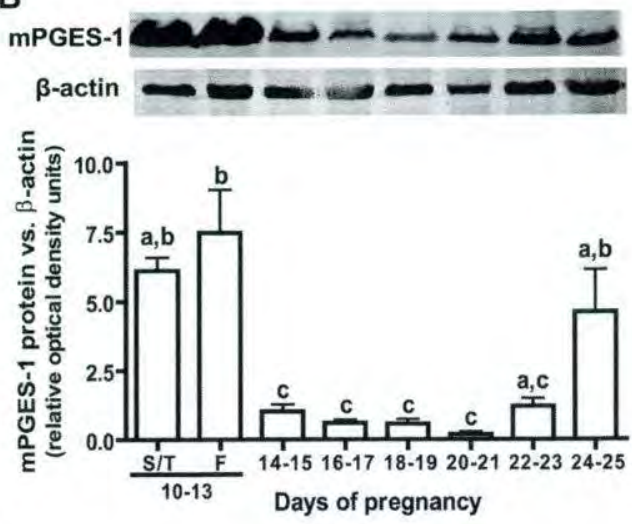

D
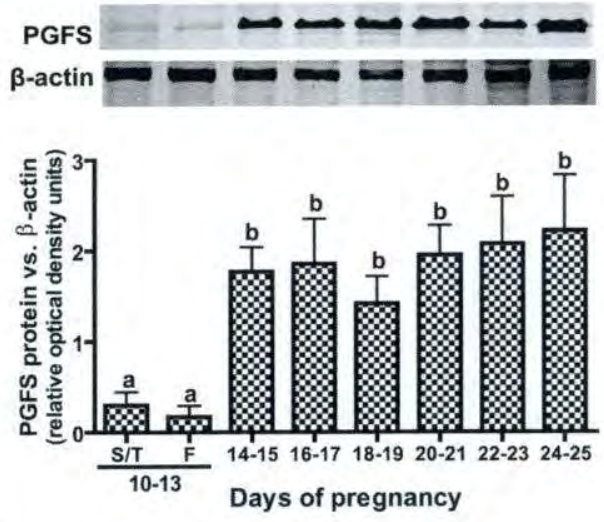

$\mathbf{F}$
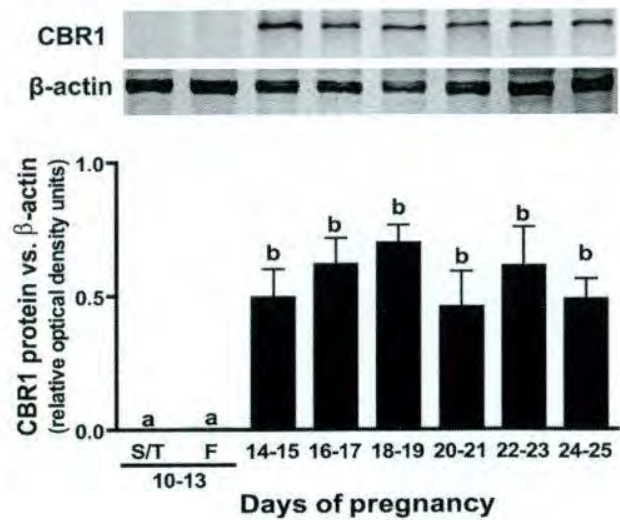

Fig. 3 Expression of PGE synthase (A, B), PGF synthase (C, D) and prostaglandin 9-ketoreductase/carbonyl reductase $(\mathbf{E}, \mathbf{F})$ in the porcine conceptus/trophoblast during early pregnancy (Waclawik \& Ziecik 2007). 
Although actions of luteal PGE2 in autoregulation of CL function cannot be excluded, synthesis of PGE2 in the conceptus and the endometrium likely contributes to the process of maternal recognition of pregnancy (Waclawik et al. 2008, Wasielak et al. 2008, Ziecik et al. 2008).

Lysophosphatidic acid (LPA)

LPA influences PG synthesis by increasing endometrial PTGS2 expression (Seo et al. 2008). Content and type of this phospholipid-derived mediator in uterine lumen differs between day 12 of the estrous cycle and pregnancy. LPA acts through specific G-protein coupled receptors LPA1-LPA4 and LPA3 is the dominant receptor in the porcine endometrium. Ye et al. (2005) indicated a critical role of LPA3 mediated signaling in mouse conceptus implantation. LPA3 is localized to LE and GE and its expression is elevated by estrogen in the pig (Seo et al. 2008). Endometrial LPA3 expression is increased during early pregnancy with the highest levels on days 11-12 and its mRNA content is higher in endometrium from the gravid compared to the non-gravid uterine horn (Kaminska et al. 2008).

\section{HOxA10}

Hox (for human HOX) genes are vertebrate homologs of D. melanogaster homeotic genes, that determine the identity of specific body segments. Recently, HoxA10 gene has attracted more attention, because it plays a role in uterine development. In mice, targeted disruption of expression of this transcription factor results in implantation failure (Benson et al. 1996). Moreover, this gene was implicated in the control of endometrial PTGS2 expression and PG synthesis in mice (Paria et al. 2002). In human, ovarian steroid-regulated HOXA10 expression in endometrium and peak expression of HOXA10 during the window of implantation suggests an important role for this gene in controlling uterine receptivity (Daftary \& Taylor 2006). Our latest studies showed up-regulation of endometrial HoxA10 during implantation in the pig (Kaczmarek et al. 2009a) and the stimulatory effect of estradiol-17 $\beta$ on its expression in endometrium (A Blitek, unpublished).

\section{Wnt}

HoxA10 gene expression may be regulated by Wnt (Bartol et al. 2006). Wnt may mediate trophoblast-epithelial interactions critical for uterine receptivity to implantation (Hayashi et al. 2007). Our recent research indicates that Wnt4 mRNA expression does not change significantly in the endometrium during the estrous cycle and early gestation whereas level of Wnt5a is higher during early pregnancy (Kiewisz et al. 2009). Moreover, expression of Wnt4 is down-regulated and Wnt5a and E-cadherin up-regulated in the CL during early pregnancy (J Kiewisz, unpublished).

\section{Luteinizing hormone receptors}

LH is able to increase PGE2 secretion and PTGS2 expression in the endometrium (Blitek et al. 2007). Additionally, estrogen administration between days 11-15 after estrus results in an increase of LH-induced PGE2 release from endometrium in vitro (G Bodek, A Ziecik, unpublished). Thus, it is possible that conceptus estrogen maintains endometrial LHR expression ensuring a higher output of PGE2. However, only simultaneous action of estradiol-17 $\beta$ and 
progesterone results in increased PGE2 secretion in response to $\mathrm{LH}$ in stromal cells (Blitek et al. 2007). Therefore, the endometrial expression of LHR during early pregnancy may also be involved in the luteoprotective action of $\mathrm{LH}$.

\section{Uterine receptivity and the establishment of pregnancy}

Pigs have a true epitheliochorial placenta in which LE remains intact throughout pregnancy. Hormonally regulated signals from the ovary induce essential changes manifested by proliferation, differentiation, and spatiotemporal expression of specific biological molecules, leading to a temporary state of uterine receptivity for implantation. This state may be further enhanced by additional factors secreted by conceptus. However, some changes are independent of conceptus presence and controlled mainly by progesterone (for review, see Bowen \& Burghardt 2000). Sustained stimulation of the endometrium by progesterone over 7-8 days causes a loss of progesterone receptors (PR) from LE and GE by day 10 of the estrous cycle and pregnancy, which is highly associated with the development of endometrial receptivity for conceptus implantation (for review, see Geisert et al. 2006). Since PR are maintained in stroma and myometrium, the effects of ovarian progesterone on expression of many factors in LE may be mediated indirectly by either progesterone-induced progestamedins produced by PR-positive stromal cells or by induction of molecules in LE that causes loss of PR to regulate expression of endometrial genes (Geisert et al. 2006, Ka et al. 2007).

Progesterone induces down-regulation of PR from LE and GE resulting in the decrease in mucin-1 from the apical surface of LE and exposure of integrins for trophoblast attachment (Bowen et al. 1996). Expression of $\alpha 4, \alpha 5, \beta 1$ integrin subunits increases on days $11-15$ in both cyclic and pregnant gilts and is regulated by progesterone alone or together with estrogen (Bowen et al. 1996). Secreted phosphoprotein 1 (SPP1), induced by estrogen in LE during apposition phase of implantation, is a potent adhesion protein mediating attachment between trophoblast and LE (White et al. 2005).

\section{Cytokines}

Among cytokines, interleukin-1 $\beta$ (IL-1 $\beta$ ) seems to play a pivotal role during maternal recognition of pregnancy, and may be involved in cell adhesion and other cytokine stimulation. Abundant levels of IL- $1 \beta$ secreted by the conceptus are associated with rapid trophoblast elongation (Ross et al. 2003). Moreover, Geisert et al. (2006) suggested that IL-1 $\beta$, an inducer of phospholipase A2, regulates arachidonic acid release from cell membrane, thus ensuring the membrane fluidity necessary for trophoblast remodeling during conceptus elongation and contributing to PG synthesis (Fig. 2). Interferon $\gamma$ (INF $\gamma$ ) and interferon $\delta$ (INF $\delta$ ) of conceptus origin, IL-6 of conceptus and endometrial origin and leukaemia inhibitory factor (LIF) produced by endometrium (Modric et al. 2000, Joyce et al. 2007) may also serve as conceptus-maternal signaling molecules involved in the proliferation, differentiation and cell survival that is associated with conceptus growth and implantation.

\section{Growth factors}

Growth factors are also implicated in conceptus development and successful establishment of pregnancy since endometrial expression of fibroblast growth factor-7 (FGF-7), transforming growth factor $\beta$ (TGF $\beta$ ), vascular endothelial growth factor (VEGF) and uterine lumen content of insulin-like growth factor-I (IGF-I) are elevated on days 12-13 of pregnancy and may be 
regulated by estrogen and/or progesterone (for review, see Ziecik et al. 2006). TGF $\beta$ stimulates expression of extracellular matrix molecules and integrins as well as proteases and protease inhibitors to facilitate conceptus-uterus connections during implantation and to limit trophoblast invasiveness (Burghardt et al. 2002). Additionally, IGF-I increases steroidogenesis by stimulation of P450 aromatase expression in filamentous conceptuses (Green et al. 1995). Transition from spherical to filamentous trophoblast is associated with the decrease of IGF binding proteins (IGFBP) in the uterine lumen that regulates IGF bioavailability (Geisert et al. 2006). Both IGF-I and PGE2 stimulate VEGF expression in stromal cells during maternal recognition of pregnancy, which may result in growth and remodeling of endometrial vasculature (Kaczmarek et al. 2008). Additionally, conceptus VEGF164 expression increases gradually with conceptus development until day 16 of pregnancy (Kaczmarek et al. 2009b) suggesting that VEGF164 may induce endometrial vascular permeability and edema during implantation.

The VEGF ligand-receptor system is involved in maintenance and stabilization of the vascular bed in CL during pregnancy. PGE2-stimulated VEGF secretion by luteal cells on days 10-12 of pregnancy suggest that the luteoprotective actions of PGE2 may be partially mediated by luteal VEGF (Kowalczyk et al. 2008). Interestingly, VEGF soluble receptor (sVEGFR-1) mRNA levels are lower in the CL on day 12 of pregnancy compared to the estrous cycle (Kaczmarek et al. 2009b). Down-regulation of sVEGFR-1 (strong endogenous antagonist of VEGF) and the consequent elevation of bioavailable VEGF may sustain progesterone production by increasing luteal capillary permeability, which may aid transport of PGs from the circulation and delivery of cholesterol to the luteal cells.

\section{Conclusions}

The conceptus affects the lipid signaling system (prostaglandin and LPA) as well as HoxA10 and Wnt (factors which may be involved in PG synthesis) in the porcine endometrium in order to inhibit luteolysis and/or to create the appropriate uterine environment for conceptus development and implantation (Fig. 2). Conceptus estrogen may prevent luteolysis through modification of expression of the enzymes involved in PG synthesis, reducing release of PGF $2 \alpha$ and favoring PGE2 release on days 10-13 of pregnancy. Down-regulation of luteal sVEGFR-1 may be supportive of $\mathrm{CL}$ function during maternal recognition of pregnancy. Although it is evident that estrogen and progesterone induce essential proliferative and differentiative changes in the endometrium leading to a temporary state of uterine receptivity, a number of growth factors, cytokines and extracellular matrix and adhesion molecules are required to establish the necessary dialog between the conceptus and endometrium (Fig. 4).

\section{Acknowledgements}

We thank Dr Henry N. Jabbour for reviewing the manuscript. Studies described in this manuscript are supported partially by funds from the State Committee for Scientific Research in Poland (grants NN311319135 and N31104732/2777). A. Waclawik is the recipient of Domestic Grant for Young Scientist from the Foundation for Polish Science. J. Kiewisz is funded by the President of Polish Academy of Sciences and the European Social Fund. 


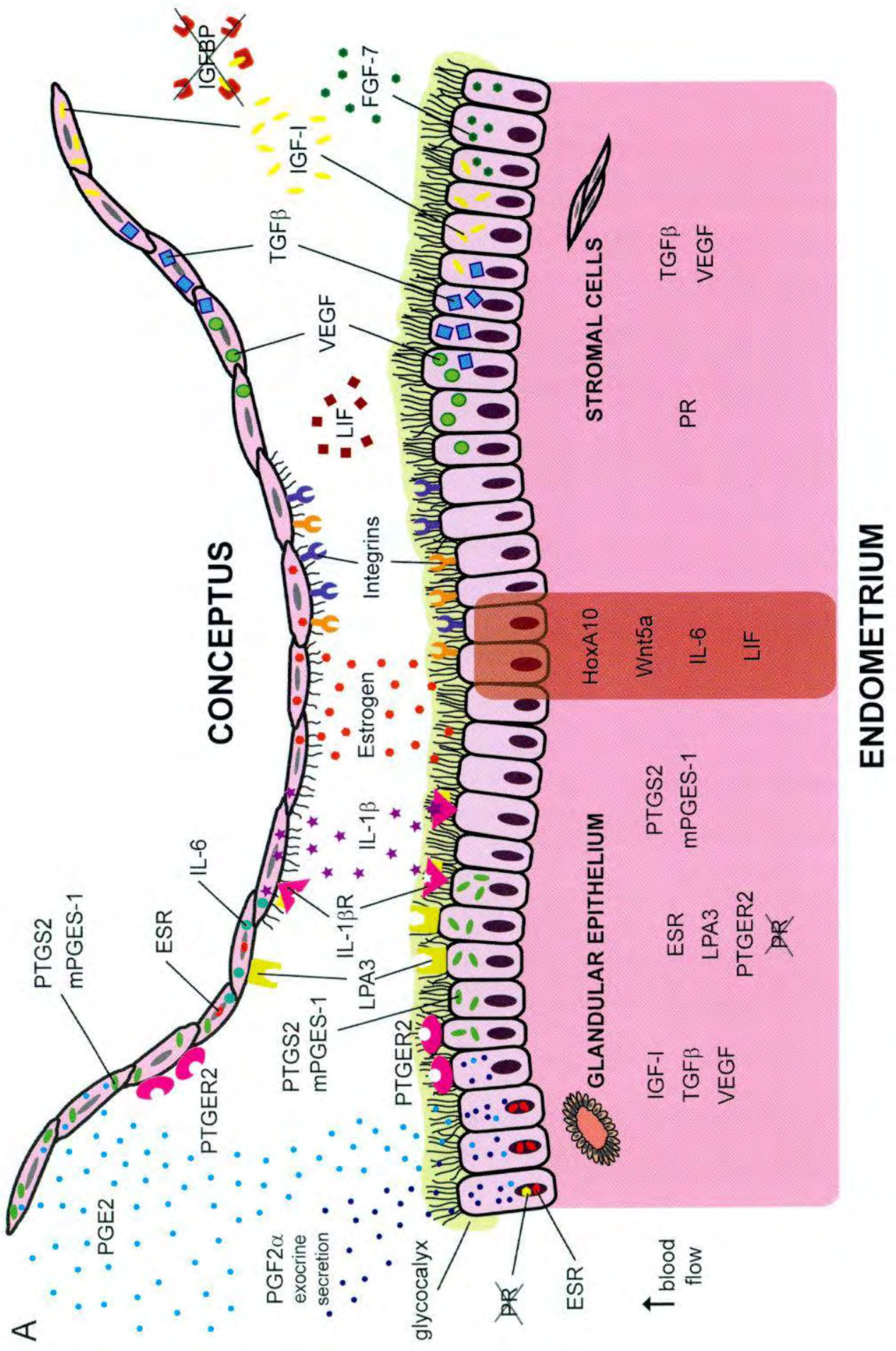




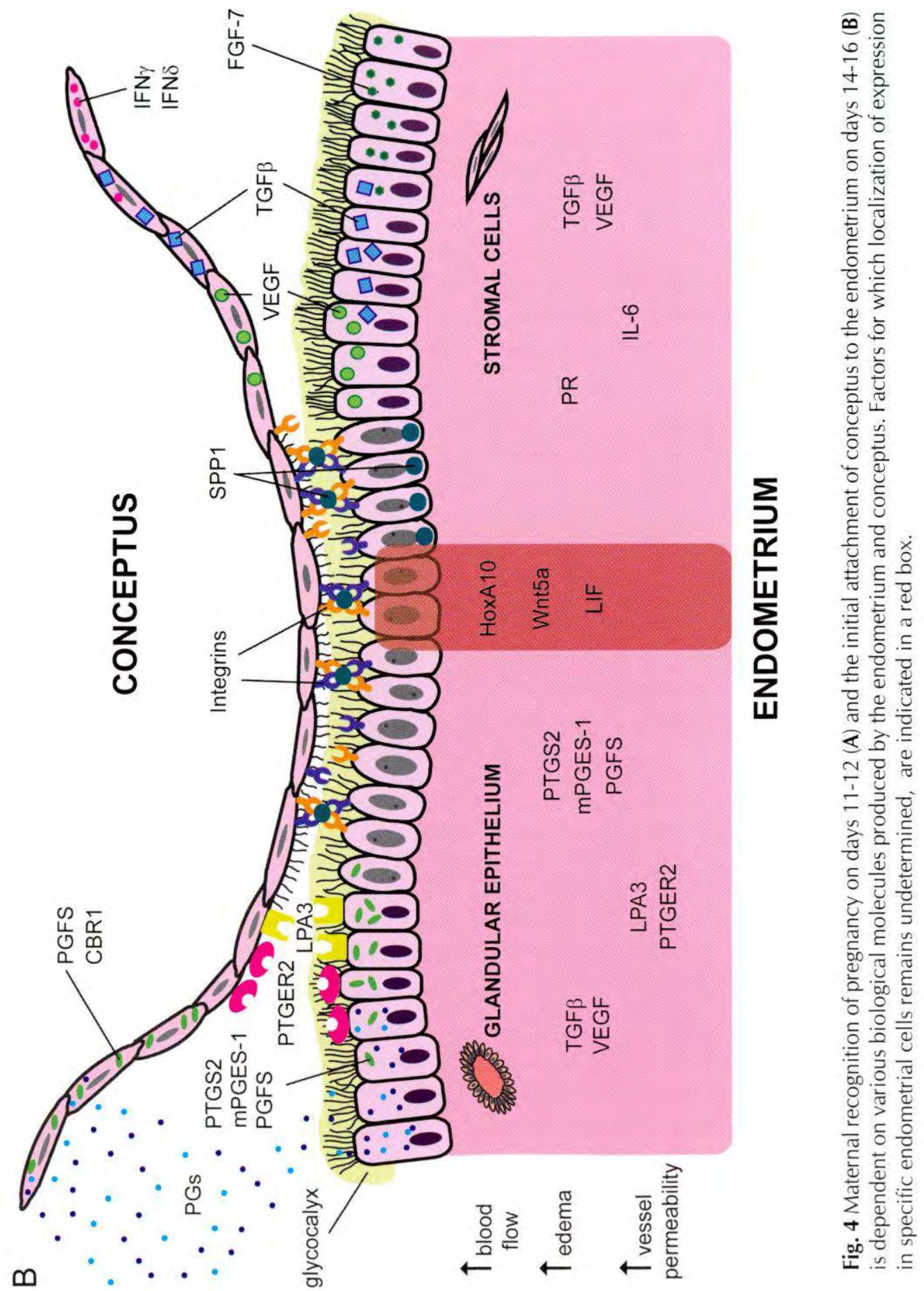




\section{References}

Akinlosotu BA, Diehl JR \& Gimenez T 1986 Sparing effects of intrauterine treatment with prostaglandin $\mathrm{E}_{2}$ on luteal function in cycling gilts. Prostaglandins 32 291-299.

Bartol FF, Wiley AA \& Bagnell CA 2006 Uterine development and endometrial programming. In: Control of Pig Reproduction VII pp 113-130 Eds CJ Ashworth \& RR Kraeling. Nottingham: Nottingham University Press.

Bazer FW \& Thatcher WW 1977 Theory of maternal recognition of pregnancy in swine based on estrogen controlled endocrine versus exocrine secretion of prostaglandin $\mathrm{F}_{2 \alpha}$ by the uterine endometrium. Prostaglandins 14 397-401.

Bazer FW, Geisert RD, Thatcher WW \& Roberts RM 1982 The establishment and maintenance of pregnancy. In Control of Pig Reproduction, pp 227-253. Eds DJA Cole \& GR Foxcroft. London: Butterworth Scientific.

Benson GV, Lim H, Paria BC, Satokata I, Dey SK \& Maas RL 1996 Mechanisms of reduced fertility in Hoxa-10 mutant mice: uterine homeosis and loss of maternal Hoxa-10 expression. Development 122 2687-2696.

Blitek A \& Ziecik AJ 2006 Role of tumour necrosis factor alpha in stimulation of prostaglandins $\mathrm{F}$ (2alpha) and $E(2)$ release by cultured porcine endometrial cells. Reproduction in Domestic Animals 41 562-567.

Blitek A, Mendrzycka AU, Bieganska MK, Waclawik A \& Ziecik AJ 2007 Effect of steroids on basal and $\mathrm{LH}$-stimulated prostaglandin $\mathrm{F}_{20}$ and $\mathrm{E}_{2}$ release and cyclooxygenase-2 expression in cultured porcine endometrial stromal cells. Reproductive Biology 7 73-88.

Boonyaprakob U, Gadsby JE, Hedgpeth V, Routh P \& Almond GW 2003 Cloning of pig prostaglandin $F_{2 a}$ (FP) receptor CDNA and expression of its $\mathrm{mRNA}$ in the corpora lutea. Reproduction 125 53-64.

Bowen JA, Bazer FW \& Burghardt RC 1996 Spatial and temporal analyses of integrin and Muc-1 expression in porcine uterine epithelium and trophectoderm in vivo. Biology of Reproduction 55 1098-1106.

Bowen JA \& Burghardt RC 2000 Cellular mechanisms of implantation in domestic farm animals. Seminars in Cell \& Developmental Biology 11 93-104.

Burghardt RC, Johnson GA, Jaeger LA, Ka H, Garlow JE, Spencer TE \& Bazer FW 2002 Integrins and extracellular matrix proteins at the maternal-fetal interface in domestic animals. Cells Tissues Organs 172 202-217.

Christenson LK, Farley DB, Anderson LH \& Ford SP 1994 Luteal maintenance during early pregnancy in the pig: role for prostaglandin $\mathrm{E}_{2}$. Prostaglandins 47 61-75.

Conley AJ \& Ford SP 1989 Direct luteotrophic effect of oestradiol- $17 \beta$ on pig corpora lutea. Journal of Reproduction and Fertility $\mathbf{8 7}$ 125-131.

Daftary GS \& Taylor HS 2006 Endocrine regulators of HOX genes. Endocrine Reviews 27 331-355.

Davis DL \& Blair RM 1993 Studies of uterine secretions and products of primary cultures of endometrial cells in pigs. Journal of Reproduction and Fertility Supplement 48 143-155.

Ford SP \& Christenson LK 1991 Direct effects of oestradiol$17 \beta$ and prostaglandin $E_{2}$ in protecting pig corpora lutea from a luteolytic dose of prostaglandin $\mathrm{F}_{2 \alpha}$. Journal of Reproduction and Fertility 93 203-209.

Frank M, Bazer FW, Thatcher WW \& Wilcox CJ 1977 A study of prostaglandin F2alpha as the luteolysin in swine: III effects of estradiol valerate on prostaglandin $F$, progestins, estrone and estradiol concentrations in the utero-ovarian vein of nonpregnant gilts. Prostaglandins 14 1183-1196.

Gadsby JE, Lovdal JA, Britt JH \& Fitz TA 1993 Prostaglandin $\mathrm{F}_{2 \alpha}$ receptor concentrations in corpora lutea of cycling, pregnant, and pseudopregnant pigs. Biology of Reproduction 49 604-608.

Garverick HA, Polge C \& Flint AP 1982 Oestradiol administration raises luteal $\mathrm{LH}$ receptor levels in intact and hysterectomized pigs. Journal of Reproduction and Fertility 66 371-377.

Geisert RD, Thatcher WW, Roberts RM \& Bazer FW 1982 Establishment of pregnancy in the pig. III. Endometrial secretory response to estradiol valerate administered on day 11 of the estrous cycle. Biology of Reproduction 27 957-965.

Geisert RD, Zavy MT, Moffatt RJ, Blair RM \& Yellin T 1990 Embryonic steroids and the establishment of pregnancy in pigs. Journal of Reproduction and Fertility Supplement 40 293-305.

Geisert RD, Brenner RM, Moffatt J, Harney JP, Yellin T \& Bazer FW 1993 Changes in oestrogen receptor protein, mRNA expression and localization in the endometrium of cyclic and pregnant gilts. Reproduction, Fertility \& Development 5 247-260.

Geisert RD, Ross JW, Ahworth MD, White FJ, Johnson GA \& DeSilva U 2006 Maternal recognition of pregnancy signal or endocrine disruptor: the two faces of oestrogen during establishment of pregnancy in the pig. In Control of Pig Reproduction VII, pp 131-145. Eds CJ Ashworth \& RR Kraeling. Nottingham: Nottingham University Press.

Green ML, Simmen RC \& Simmen FA 1995 Developmental regulation of steroidogenic enzyme gene expression in the periimplantation porcine conceptus: a paracrine role for insulin-like growth factor-I. Endocrinology 136 3961-3970.

Gregoraszczuk EL \& Michas N 1999 Progesterone and estradiol secretion by porcine luteal cells is influenced by individual and combined treatment with prostaglandins $E_{2}$ and $F_{2 a}$ throughout the estrus cycle. Prostaglandins and Other Lipid Mediators 57 231-241.

Hayashi K, Burghardt RC, Bazer FW \& Spencer TE 2007 WNTs in the Ovine Uterus: Potential Regulation of Peri-implantation Ovine Conceptus Development. Endocrinology 148 3496-3506.

Hunter RH \& Poyser NL 1982 Uterine secretion of prostaglandin F2 alpha in anaesthetized pigs during 
the oestrous cycle and early pregnancy. Reproduction, Nutrition, Development 22 1013-1023.

Joyce MM, Burghardt RC, Geisert RD, Burghardt JR, Hooper RN, Ross JW, Ashworth MD, Johnson GA 2007 Pig conceptuses secrete estrogen and interferons to differentially regulate uterine STAT1 in a temporal and cell type-specific manner. Endocrinology 148 4420-4431.

Ka H, Al-Ramadan S, Erikson DW, Johnson GA, Burghardt RC, Spencer TE, Jaeger LA \& Bazer FW 2007 Regulation of expression of fibroblast growth factor 7 in the pig uterus by progesterone and estradiol. Biology of Reproduction 77 172-180.

Kaczmarek MM, Blitek A, Kaminska K, Bodek G, Zygmunt M, Schams D \& Ziecik AJ 2008 Assessment of VEGF-receptor system expression in the porcine endometrial stromal cells in response to insulin-like growth factor-I, relaxin, oxytocin and prostaglandin $E_{2}$. Molecular and Cellular Endocrinology 291 33-41.

Kaczmarek MM, Balcerowicz D, Kiewisz J, Ziecik AJ \& Blitek A 2009a Expression of HoxA10 in early pregnant endometrium and conceptus in pigs with natural and hormonally-induced ovulation. 8th International Conference on Pig Reproduction, Banff, Canada, 1-4 June 2009, Program \& Abstract Book, pp 144, abstr 252-17.

Kaczmarek MM, Kiewisz J, Schams D \& Ziecik A] 2009b Expression of VEGF-receptor system in conceptus during peri-implantation period and endometrial and luteal expression of soluble VEGFR-1 in the pig. Theriogenology 71 1298-1306.

Kaminska K, Wasielak M, Bogacka I, Blitek M \& Bogacki M 2008 Quantitative expression of lysophosphatidic acid receptor 3 gene in porcine endometrium during the periimplantation period and estrous cycle. Prostaglandins and Other Lipid Mediators 85 26-32.

Kayser JP, Kim JG, Cerny RL \& Vallet JL 2006 Global characterization of porcine intrauterine proteins during early pregnancy. Reproduction 131 379-388.

Kiewisz J, Kaczmarek MM, Blitek A, Bodek G \& Ziecik AJ 2009 The expression of Wnt4, Wnt5a, Wnt7a, $\beta$-catenin and E-cadherin genes in the endometrium during the reproductive cycle and early pregnancy in pigs. 8th International Conference on Pig Reproduction, Banff, Canada, 1-4 June 2009, Program \& Abstract Book, pp 147, abstr 252-20.

Kotwica G, Franczak A, Okrasa S \& Kotwica J 1999 Effect of an oxytocin antagonist on prostaglandin $F_{2 \alpha}$ secretion and the course of luteolysis in sows. Acta Veterinaria Hungarica 47 249-262.

Kowalczyk AE, Kaczmarek MM, Schams D \& Ziecik A] 2008 Effect of prostaglandyn $E_{2}$ and tumor necrosis factor $\alpha$ on the VEGF-receptor system expression in cultured porcine luteal cells. Molecular Reproduction and Development 75 1558-1566.

Kowalski AA, Graddy LG, Vale-Cruz DS, Choi I, Katzenellenbogen BS, Simmen FA \& Simmen RC 2002 Molecular cloning of porcine estrogen receptor-beta complementary DNAs and developmental expression in periimplantation embryos. Biology of Reproduction $66760-769$.
Krzymowski T \& Stefanczyk-Krzymowska S 2004 The oestrous cycle and early pregnancy - a new concept of local endocrine regulation. The Veterinary Journal 168 285-296.

Krzymowski T \& Stefanczyk-Krzymowska S 2008 The role of the endometrium in endocrine regulation of the animal oestrous cycle. Reproduction in Domestic Animals 43 80-91.

Laforest JP \& King GJ 1992 Structural and functional aspects of porcine endometrial capillaries on days 13 and 15 after oestrus or mating. Journal of Reproduction and Fertility 94 269-277.

Modric T, Kowalski AA, Green ML, Simmen RC \& Simmen FA 2000 Pregnancy-dependent expression of leukaemia inhibitory factor (LIF), LIF receptor-beta and interleukin-6 (IL-6) messenger ribonucleic acids in the porcine female reproductive tract. Placenta $\mathbf{2 1}$ 345-353.

Moeljono MP, Thatcher WW, Bazer FW, Frank M, Owens LJ, Wilcox CJ 1977 A study of prostaglandin F2alpha as the luteolysin in swine: II Characterization and comparison of prostaglandin F, estrogens and progestin concentrations in utero-ovarian vein plasma of nonpregnant and pregnant gilts. Prostaglandins $\mathbf{1 4}$ 543-555.

Paria BC, Reese J, Das SK \& Dey SK 2002 Deciphering the cross-talk of implantation: advances and challenges. Science 296 2185-2188.

Ross JW, Malayer JR, Ritchey JW \& Geisert RD 2003 Characterization of the interleukin-1 beta system during porcine trophoblastic elongation and early placental attachment. Biology of Reproduction 69 1251-1259.

Sample GL, Blackwell DM, Kubotsu SL \& Mirando MA 2000 Endocrine secretion of prostaglandin $\mathrm{F}_{2 \alpha}$ in cyclic gilts is decreased by intrauterine administration of exogenous oxytocin. Animal Reproduction Science 84 395-406.

Sample GL, Kubotsu SL, Carnahan KG \& Mirando MA 2004 Interestrous interval of cyclic gilts is decreased by systemic but not intra-uterine administration of exogenous oxytocin. Journal of Animal Science $\mathbf{7 8}$ 2393-2398.

Seo H, Kim M, Choi Y, Lee CK \& Ka H 2008 Analysis of lysophosphatidic acid (LPA) receptor and LPA-induced endometrial prostaglandin-endoperoxide synthase 2 expression in the porcine uterus. Endocrinology 149 6166-6175.

Stefanczyk-Krzymowska S, Wasowska B, Chłopek J, Gilun P, Grzegorzewski W \& Radomski M 2006 Retrograde and local destination transfer of uterine prostaglandin E2 in early pregnant sow and its physiological consequences. Prostaglandins \& Other Lipid Mediators 81 71-79.

Stepien A, Shemesh M \& Ziecik AJ 1999 Luteinizing hormone receptor kinetic and $\mathrm{LH}$-induced prostaglandin production throughout the oestrous cycle in porcine endometrium. Reproduction, Nutrition, Development 39 663-674.

Uzumcu M, Braileanu GT, Carnahan KG, Ludwig TE \& Mirando MA 1998 Oxytocin-stimulated phosphoinositide hydrolysis and prostaglandin $F$ 
secretion by luminal epithelial, glandular and stromal cells from pig endometrium. I. Response of cyclic pigs on day 16 postestrus. Biology of Reproduction 59 1259-1265.

Vallet JL, Christenson RK, Trout WE \& Klemcke HG 1998 Conceptus, progesterone, and breed effects on uterine protein secretion in swine. Journal of Animal Science 76 2657-2670.

Waclawik A \& Ziecik AJ 2007 Differentional expression of prostaglandin (PG) synthesis enzymes in conceptus during periimplantation period and endometrial expression of carbonyl reductase/prostaglandin 9-ketoreductase in the pig. Journal of Endocrinology 194 1-13

Waclawik A, Rivero-Muller A, Blitek A, Kaczmarek MM, Brokken LJ, Watanabe K, Rahman NA \& Ziecik AJ 2006 Molecular cloning and spatiotemporal expression of prostaglandin F synthase and microsomal prostaglandin E synthase-1 in porcine endometrium. Endocrinology 147 210-221.

Waclawik A, Kaczmarek MM, Kowalczyk AE, Bogacki M \& Ziecik AJ 2008 Expression of prostaglandin synthesis pathway enzymes in the porcine corpus luteum during the estrous cycle and early pregnancy. Theriogenology 70 145-152.

Waclawik A, Jabbour HN, Blitek A \& Ziecik AJ 2009 Estradiol-17ß, prostaglandin E2 (PGE2) and the prostaglandin E2 receptor are involved in PGE2 positive feedback loop in the porcine endometrium. Endocrinology (In press) (DOI:10.1210/ en.2008-1499).

Wasielak M, Glowacz M, Kaminska K, Waclawik A \& Bogacki M 2008 The influence of embryo presence on prostaglandin synthesis and prostaglandin E2 and $\mathrm{F} 2 \alpha$ content in corpora lutea during periimplantation period in the pig. Molecular Reproduction \& Development 75 1208-1216.

White FJ, Ross JW, Joyce MM, Geisert RD, Burghardt RC \& Johnson GA 2005 Steroid regulation of cell specific secreted phosphoprotein 1 (osteopontin) expression in the pregnant porcine uterus. Biology of Reproduction 73 1294-1301.

Ye X, Hama K, Contos JJ, Anliker B, Inoue A, Skinner MK, Suzuki H, Amano T, Kennedy G, Arai H, Aoki J \& Chun J 2005 LPA3-mediated lysophosphatidic acid signalling in embryo implantation and spacing. Nature 435 104-108.

Young KH, Kraeling RR \& Bazer FW 1990 Effect of pregnancy and exogenous ovarian steroids on endometrial prolactin receptor ontogeny and uterine secretory response in pigs. Biology of Reproduction 43 592-599.

Zavy MT, Bazer FW, Thatcher WW, Wilcox CJ 1980 A study of prostaglandin F2 alpha as the luteolysin in swine: V. Comparison of prostaglandin F, progestins, estrone and estradiol in uterine flushings from pregnant and nonpregnant gilts. Prostaglandins 20 837-851.

Ziecik AJ, Blitek A, Kaczmarek MM, Waclawik A \& Bogacki M 2006 Inhibition of luteolysis and embryouterine interactions during the peri-implantation period in pigs. In Control of Pig Reproduction VII, pp 147-161. Eds CJ Ashworth \& RR Kraeling. Nottingham: Nottingham University Press.

Ziecik AJ, Waclawik A \& Bogacki M 2008 Conceptus signals for establishment and maintenance of pregnancy in pigs - lipid signaling system. Experimental and Clinical Endocrinology \& Diabetes 116 443-449.

Zorrilla LM, Irvin MS \& Gadsby JE 2009 Protein kinase $\mathrm{C}$ isoforms in the porcine corpus luteum: temporal and spatial expression patterns. Domestic Animal Endocrinology 36 173-185. 